\title{
SOME DURABILITY PROPERTIES OF ALKALI ACTIVATED MATERIALS (AAM) PRODUCED WITH CERAMIC POWDER AND MICRO CALCITE
}

\author{
\#SELÇUKMEMİş*,GÖKHANKAPLAN**,HASBİYAPRAK*,M.UĞURYILMAZOĞLU*,MÜTEVVELLİÖZKANI.G.* \\ *Kastamonu University, Faculty of Engineering and Architecture, Department of Civil Engineering, Kastamonu, Turkey \\ ** Kastamonu University, Kastamonu Vocational Schools, Kastamonu, Turkey \\ "E-mail: smemis@kastamonu.edu.tr
}

Submitted April 21, 2018; accepted July 17, 2018

\begin{abstract}
Keywords: Ceramic Powder, Calcareous Aggregate, Geopolymer, Sodium Silicate, Accelerated Curing
This study aims to produce alkali-activated materials (AAM) under different curing conditions using a ceramic powder (CP) instead of a blast furnace slag (BFS) and a micro calcite (McK) instead of a calcareous aggregate. The water/binder (W/B) ratios of the AAMs range from 0.30 - 0.42 and the sodium silicate (SS) ratios range from $15-60 \%$. They were subjected to curing process in $80^{\circ} \mathrm{C}$ water and in an oven, in the air, and with a chemical curing method. Consequently, it was observed that an increase in the ratios of SS and W/B and using $25 \%$ McK with a spherical structure, increased the workability. An increase in the $C P$ and $M c K$ usage ratios reduced the 28-day compressive strengths. Using the CP while designing the $A A M s$, which were exposed to sodium sulfate and sulfuric acid, reduced the losses in strength. Also, an increase in the CP ratio has a positive influence on the AAM as it increases the high-temperature endurance of the mortars. For conventional concrete, permeability in freeze-thaw resistance is an important factor for AAMs. Hence, using McK in AAMs increases the freeze-thaw resistance. Consequently, it was observed that using a CP up to $40 \%$ influences the AAM positively.
\end{abstract}

\section{INTRODUCTION}

Besides the research that aims to improve environmental sustainability, there is also research conducted for the emergence of new binders that will replace conventional cement (OPC) to ensure the durability of structures. During the production of cement using conventional methods, a large part of the $\mathrm{CO}_{2}$ that is released in the atmosphere is generated by the following three processes: the calcination process during cement clinker production $(0.33 \mathrm{~kg})$, the calcite decarbonisation process $(0.53 \mathrm{~kg})$, and the required power generation process. Thus, it is known that a high amount of $\mathrm{CO}_{2}$ is released per 1 tonne of cement clinker production. Apart from the negative environmental impacts encountered in concretes produced using OPC, the loss of strength, which is encountered in existing concrete-based structures and caused by inevitable fragmentation (damage), is also another adverse effect [1], [2]. In fact, the durability of reinforced concrete structures depends on the content of $\mathrm{Ca}(\mathrm{OH})_{2}$ present in the cement, which is a hydration product of cement and constitutes about $25 \%$ in cement composed of $60-65 \% \mathrm{CaO}$ [3]. On the contrary, the pozzolanas frequently used in reducing this loss of strength are generally secondary waste products, which are used to strengthen the $\mathrm{C}-\mathrm{S}-\mathrm{H}$ gel by decreasing the amount of $\mathrm{Ca}(\mathrm{OH})_{2}$ and give concrete more resistance against an aggressive environment $[2,3]$.
Geopolymer concrete is a special type of concrete, which is produced using binders that are activated by alkalis, such as fly ash, molten lead slag, ground granulated BFS, and palm oil fuel agglomerates, which are generally considered as industrial waste [4-9]. Geopolymers have the potential to overcome major concerns about the storage and disposal of hazardous industrial wastes using these wastes as cement material. It is important to understand the durability properties of these new binders for using the geopolymer concrete in commercial applications [9].

The reaction mechanisms of fly ash-based geopolymer concretes due to corrosion, sulfate and acid fouling are being investigated in many studies [10-12]. Although some properties of the geopolymer concretes are superior, there are conflicting results in regard to their resistance to the effects such as freezing-thawing $[13,14]$. But the studies done by Bilek emphasised that the freezing-thawing resistance of a geopolymer concrete is better [15]. Furthermore, geopolymer concretes generally have a lower chloride diffusion coefficient than conventional concrete and exhibit better chloride resistance due to their special gel compositions and pore structures [16-23]. However, geopolymer concretes have higher resistance to sulfates than that of conventional concrete. $\mathrm{Ca}(\mathrm{OH})_{2}$ does not form in geopolymer concretes and the $\mathrm{Ca} / \mathrm{Si}$ ratio of $\mathrm{C}-(\mathrm{N})-\mathrm{A}-\mathrm{S}-\mathrm{H}$ is lower. As a result, geopolymer concretes have different mechanisms 
against a sulfate attack. Sulfate resistance of geopolymer concretes depend not only on the sulfate concentration and the type of cations, but also on the gel compositions $[10,16,24-27]$.

Hydrated cement paste is an alkaline component and gets easily affected by acidic solutions. As a result of the acid effect and calcium dissolution, structural damage and loss of performance occur in conventional concrete. Many studies have determined that geopolymer concretes exhibit better acid resistance than conventional concrete owing to the differences in the structure of the hydration products. The dissolution of calcium sulphoaluminates with $\mathrm{Ca}(\mathrm{OH})_{2}$ in Portland cement forms a very porous worn layer by causing decalcification of $\mathrm{C}-\mathrm{S}-\mathrm{H}$. But in geopolymer concretes, the typically low $\mathrm{CaO} / \mathrm{SiO}_{2}$ ratio of $\mathrm{C}-\mathrm{A}-\mathrm{S}-\mathrm{H}$ with low initial permeability of the alkali-activated slag samples form a consistent aluminosilicate structure even after decalcification. This effect prevents further leakage of the acids and allows geopolymer concretes to gain higher acid resistance [28-30]. However, geopolymer concretes retained in an $\mathrm{HCl}$ solution, zeolites formed in the alkali-activated fly ash binders were found to be damaged, independent of the type of activator used in the dealuminization of the $\mathrm{N}-\mathrm{A}-\mathrm{S}-\mathrm{H}$ gel [19].

It has been observed that geopolymer concretes are generally more resistant to acid and sulfate effects than conventional concrete. There is no definite finding yet for the durability of geopolymer concretes against effects, such as freezing-thawing and high temperature [31]. In this study, CP instead of BFS and McK instead of calcareous aggregate were used in the AAM design produced under different curing conditions. Some durability properties, such as the freezing-thawing resistance, the high-temperature endurance, the sulfate, and acid resistance of AAMs produced using $\mathrm{CP}$ and $\mathrm{McK}$ have been investigated.

\section{EXPERIMENTAL}

\section{Materials}

Ceramic powder (CP) and blast furnace slag (BFS) were used as binders in the production of composites. BFS was obtained from the OYAK Erdemir plant and has a specific surface area of $4.800 \mathrm{~cm}^{2} \cdot \mathrm{g}^{-1}$. In the amorphous BFS, there are phases, such as $\mathrm{Ca}_{3} \mathrm{Si}_{2} \mathrm{O}_{7}$ (Rankinite), $2 \mathrm{CaO} \cdot \mathrm{Al}_{2} \mathrm{O}_{3} \cdot \mathrm{SiO}_{2}$ (Gehlenite), $\mathrm{\beta CaO} \cdot \mathrm{SiO}_{2}$ (Wollastonite), and $\mathrm{CaO} \cdot \mathrm{Al}_{2} \mathrm{O}_{3} \cdot 2 \mathrm{SiO}_{2}$ (Anorthite). The alkalinity coefficient of BFS and the hydration module was calculated to be $0.60\left[\mathrm{~Kb}=(\mathrm{CaO}+\mathrm{MgO}) /\left(\mathrm{SiO}_{2}+\mathrm{Al}_{2} \mathrm{O}_{3}\right)\right]$ and $1.19\left[\mathrm{HM}=\left(\mathrm{CaO}+\mathrm{MgO}+\mathrm{Al}_{2} \mathrm{O}_{3}\right) / \mathrm{SiO}_{2}\right]$, respectively. The CP with a specific surface area of $3300 \mathrm{~cm}^{2} \cdot \mathrm{g}^{-1}$ has been obtained from the waste products of the company CREAVIT that has production operations in Zonguldak. The hydration modulus (HM) of the $\mathrm{CP}$ was found to be 0.52 . The chemical properties of the BFS and $\mathrm{CP}$ are given in Table 1.

Sodium silicate with a silicate modulus of $3\left(M_{s}=3\right)$ and pelleted sodium hydroxide with $97 \%$ purity were used as the activator in the composites.

Two different aggregates, limestone and micro calcite, were used in the mixtures. The grain distribution of the limestone aggregate is between 0 and $2 \mathrm{~mm}$ and the specific gravity is 2.62 . The average grain size of the calcite aggregate is about 130 microns and the specific gravity is 2.66 . The properties of the grain distributions of the aggregates are given in Figure 1.

Table 1. Chemical properties of BFS and CP.

\begin{tabular}{lccccccccc}
\hline & $\mathrm{CaO}$ & $\mathrm{SiO}_{2}$ & $\mathrm{Al}_{2} \mathrm{O}_{3}$ & $\mathrm{Fe}_{2} \mathrm{O}_{3}$ & $\mathrm{Na}_{2} \mathrm{O}$ & $\mathrm{K}_{2} \mathrm{O}$ & $\mathrm{MgO}$ & $\mathrm{SO}_{3}$ & $\mathrm{SW}$ \\
\hline BFS & 31.61 & 43.45 & 16.17 & 0.45 & 3.81 & 0.65 & 4.00 & 1.54 & 2.87 \\
$\mathrm{CP}$ & 6.10 & 47.77 & 16.47 & 0.58 & 3.92 & 0.95 & 2.36 & 0.29 & 2.66 \\
\hline
\end{tabular}

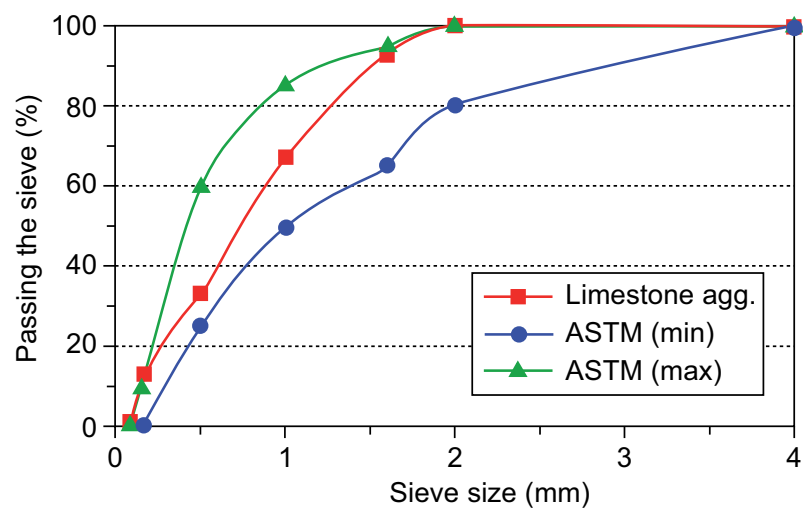

a) Limestone aggregate

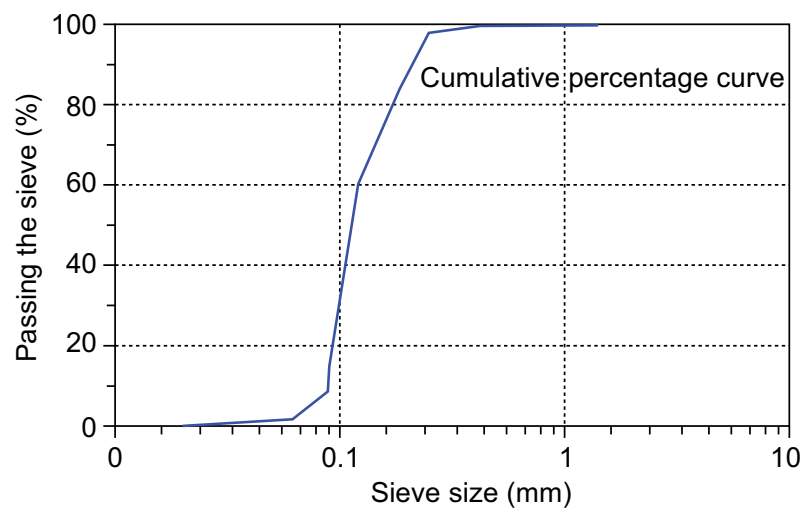

b) Micro calcite aggregate

Figure 1. Grain distributions of the aggregates. 
To increase the workability of the fresh mortars, a polycarboxylic ether based high-water reducing the chemical additive was used. The specific weight of the water reducing additive was found to be 1.07 and solid matter content to be $36.73 \%$.

\section{Experimental design}

In this study, the Taguchi method, which is one of the experiment design (DOE) methods, was used to determine the optimum mixture properties. In the first stage of the Taguchi method, optimum mixtures were determined by taking the properties of the maximum compressive strength, the minimum compressive strength, and the spreading diameter into consideration.

The CP was obtained as a result of the mechanical milling of the ceramic wastes at the factory site. Ceramic wastes were pulverised by grinding with a Bond type ball mill. The grinding process was continued until all of the CP was passed through a 90-micron sieve. The main binder of the mixtures was identified as BFS, and the $\mathrm{CP}$ was used as a substitute. The calcareous aggregate was replaced with the micro calcite that has a lower grain size. A $16 \mathrm{M}$ sodium hydroxide solution was prepared $24 \mathrm{~h}$ prior to casting. Alkali solutions $(\mathrm{SS}+\mathrm{SH})$ were used at the rate of $40 \%$ of the binding materials (BFS $+\mathrm{CP}$ ).

Table 2. Factors of the mixture properties.

\begin{tabular}{|c|c|c|c|c|}
\hline Factor & Level 1 & Level 2 & Level 3 & Level 4 \\
\hline $\mathrm{CP}(\%)$ & 20 & 30 & 40 & 50 \\
\hline $\mathrm{McK}(\%)$ & 0 & 25 & 50 & 75 \\
\hline SS (\%) & 15 & 30 & 45 & 60 \\
\hline $\mathrm{W} / \mathrm{B}$ & 0.30 & 0.34 & 0.38 & 0.42 \\
\hline $\begin{array}{l}\text { Curing } \\
\text { conditions }\end{array}$ & $\begin{array}{l}\text { Water } \\
\text { curing }\end{array}$ & $\begin{array}{c}80^{\circ} \mathrm{C} \\
\text { (Oven) }\end{array}$ & $\begin{array}{c}80^{\circ} \mathrm{C} \\
\text { (Water) }\end{array}$ & $\begin{array}{c}\text { Chemical } \\
\text { curing }\end{array}$ \\
\hline
\end{tabular}

SS and SH were used together in the mixtures. SS was chosen as the main activator type and SS was substituted with $\mathrm{SH}$. The aggregate binder ratio $(\mathrm{a} / \mathrm{b})$ in the mixtures was chosen as 1 . A chemical additive in the amount of $5 \%$ of the binder amount was used for the workability of the mortars. Furthermore, the additional water used during the production of the mortars was determined by considering the amount of water in the alkaline solutions. The chemical curing method was used for some of the mortar groups placed in moulds. A liquid chemical curing material (acrylic based) was applied 1 hour after casting to the mortar surface placed in the mould. Air curing and thermal curing in water and an oven were used for other mortar groups.

A Taguchi L16 $\left(4^{4}\right)$ experiment matrix was used for the experimental study. The factors forming the mixture properties are given in Table 2 and the mixture ratios are given in Table 3 .

Mixing, moulding,
and curing processes

The mixing process was initiated by dry mixing of the binding materials first. Afterwards alkali activators were added. After the binder materials and activators were mixed, $1 / 2$ of the additional water, and $1 / 2$ of the chemical additive were added into the mixer. In the next stage, all the aggregate was added to the mixture. After adding the aggregate to the mixture, the remaining additional water and chemical additive were added to the mixer. Details of the mixing process consisting of 8 steps are given in Figure 2.

The mortar mixtures that have been prepared were placed in $40 \times 40 \times 160 \mathrm{~mm}$ moulds. The mechanical properties were determined on the samples with $40 \times 40$ $\times 160 \mathrm{~mm}$ dimensions. Since the fresh mortar mixtures

Table 3. Material mixture ratios and quantities.

\begin{tabular}{|c|c|c|c|c|c|c|c|c|c|c|c|c|c|}
\hline \multirow[b]{2}{*}{ Mixture } & \multicolumn{5}{|c|}{ Material ratios $(\%)$} & \multicolumn{8}{|c|}{ Material quantities (g) } \\
\hline & $\mathrm{CP}$ & $\mathrm{McK}$ & SS & $\mathrm{W} / \mathrm{B}$ & $\begin{array}{c}\text { Curing } \\
\text { conditions }\end{array}$ & $\mathrm{CP}$ & BFS & SS & $\mathrm{SH}$ & Agg. & $\mathrm{McK}$ & Water & $\begin{array}{l}\text { Chem. } \\
\text { admix. }\end{array}$ \\
\hline 1 & 20 & 0 & 15 & 0.30 & Air & 200 & 800 & 60 & 340 & 1000 & 0 & 134 & 50 \\
\hline 2 & 30 & 75 & 45 & 0.34 & Air & 300 & 700 & 180 & 220 & 250 & 750 & 162 & 50 \\
\hline 3 & 40 & 25 & 60 & 0.38 & Air & 400 & 600 & 240 & 160 & 750 & 250 & 196 & 50 \\
\hline 4 & 50 & 50 & 30 & 0.42 & Air & 500 & 500 & 120 & 280 & 500 & 500 & 248 & 50 \\
\hline 5 & 20 & 25 & 30 & 0.34 & $80^{\circ} \mathrm{C}$ (Oven) & 200 & 800 & 120 & 280 & 750 & 250 & 168 & 50 \\
\hline 6 & 30 & 50 & 60 & 0.30 & $80^{\circ} \mathrm{C}$ (Oven) & 300 & 700 & 240 & 160 & 500 & 500 & 116 & 50 \\
\hline 7 & 40 & 0 & 45 & 0.42 & $80^{\circ} \mathrm{C}$ (Oven) & 400 & 600 & 180 & 220 & 1000 & 0 & 242 & 50 \\
\hline 8 & 50 & 75 & 15 & 0.38 & $80^{\circ} \mathrm{C}$ (Oven) & 500 & 500 & 60 & 340 & 250 & 750 & 214 & 50 \\
\hline 9 & 20 & 50 & 45 & 0.38 & $80^{\circ} \mathrm{C}$ (Water) & 200 & 800 & 180 & 220 & 500 & 500 & 202 & 50 \\
\hline 10 & 30 & 25 & 15 & 0.42 & $80^{\circ} \mathrm{C}$ (Water) & 300 & 700 & 60 & 340 & 750 & 250 & 254 & 50 \\
\hline 11 & 40 & 75 & 30 & 0.30 & $80^{\circ} \mathrm{C}$ (Water) & 400 & 600 & 120 & 280 & 250 & 750 & 128 & 50 \\
\hline 12 & 50 & 0 & 60 & 0.34 & $80^{\circ} \mathrm{C}$ (Water) & 500 & 500 & 240 & 160 & 1000 & 0 & 156 & 50 \\
\hline 13 & 20 & 75 & 60 & 0.42 & Chemical curing & 200 & 800 & 240 & 160 & 250 & 750 & 236 & 50 \\
\hline 14 & 30 & 0 & 30 & 0.38 & Chemical curing & 300 & 700 & 120 & 280 & 1000 & 0 & 208 & 50 \\
\hline 15 & 40 & 50 & 15 & 0.34 & Chemical curing & 400 & 600 & 60 & 340 & 500 & 500 & 174 & 50 \\
\hline 16 & 50 & 25 & 45 & 0.30 & Chemical curing & 500 & 500 & 180 & 220 & 750 & 250 & 122 & 50 \\
\hline
\end{tabular}


had self-settling property, no vibration process was applied to the moulds. The mortars placed on the moulds were removed after 24 hours and the curing process started.

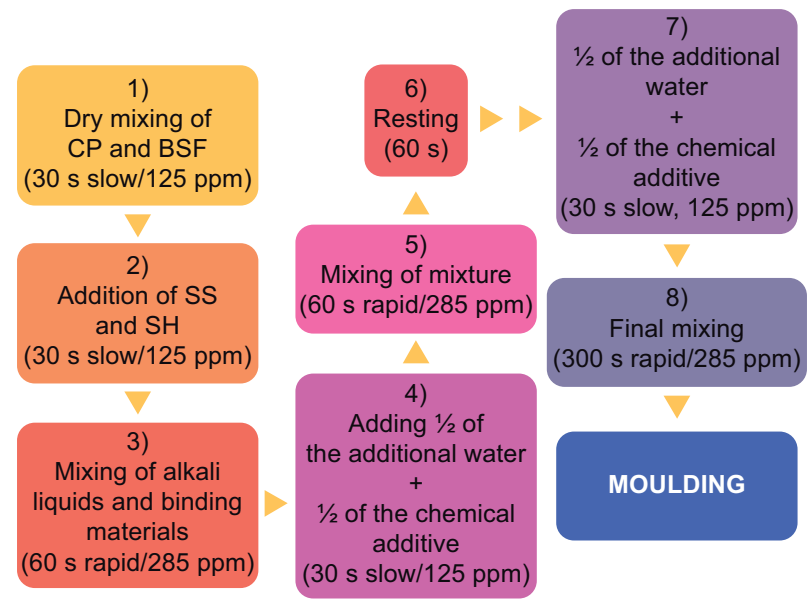

Figure 2. Mixing stages used in preparing the mortars.

Four different methods have been studied for curing the mortars. The first method involves holding the mortars in laboratory conditions (outdoors) until the experiment day. The second method consists of holding the mortars removed from the moulds until the test day in an oven at $80^{\circ} \mathrm{C}$. In the third method, the mortars were kept in $80^{\circ} \mathrm{C}$ water until the experiment day. In the fourth method, the curing was carried out using an acrylic based chemical curing material. A liquid curing material was sprayed onto the mortar surfaces $1 \mathrm{~h}$ after casting. 24 hours after mould removal, the chemical curing material was applied to the other edges of the mortars and the samples were kept in plastic bags in room conditions until the experiment day.

\section{Test methods}

The fresh state properties of the mortars were determined using a spreading table. The average of two different measurements in the $\mathrm{X}$ and $\mathrm{Y}$ directions are measured as the spreading diameter. The compressive strength tests on the $3^{\text {rd }}, 7^{\text {th }}$, and $28^{\text {th }}$ days were carried out in accordance with the ASTM C109 standard.

Some durability experiments, such as the acid, sulfate, high temperature, and freezing-thawing effect were carried out on the best 3 mixtures that were determined according to the results of optimisation made pursuant to the Taguchi L16 matrix.

$\mathrm{Na}_{2} \mathrm{SO}_{4}$ (sodium sulfate) and $5 \% \mathrm{H}_{2} \mathrm{SO}_{4}$ (sulfuric acid) were used for acid and sulfate effects. The mechanical properties of the mortars have been determined up to the $180^{\text {th }}$ day. The mortars were exposed to temperatures of $300^{\circ} \mathrm{C}, 600^{\circ} \mathrm{C}$, and $900^{\circ} \mathrm{C}$ as a high-temperature effect. In the high temperature tests, a laboratory chamber furnace with a temperature increase rate of $15^{\circ} \mathrm{C} \cdot \mathrm{min}^{-1}$ was used. The samples were first heated at $105^{\circ} \mathrm{C}$ for 3 hours and then exposed to high temperature. After a 1 -hour exposure to $300^{\circ} \mathrm{C}, 600^{\circ} \mathrm{C}$, and $900^{\circ} \mathrm{C}$ temperatures, the mortars were subjected to an air-cooling process. The compressive strength and dynamic elasticity modulus of the mortars exposed to high-temperature effects were determined. In the freezing-thawing test, 50, 100, and 200 cycles were applied and the mechanical properties of the mortars were determined. The freezing-thawing test was carried out in accordance with the ASTM C 666 standard. The mortars were subjected to a freezing effect at $-20^{\circ} \mathrm{C}$ for 6 hours, followed by a thawing process at $+4^{\circ} \mathrm{C}$ for 3 hours.

\section{RESULTS AND DISCUSSION \\ Fresh state properties of the mortars}

The effect of the CP and McK ratios on the spreading diameters is shown in Figure 3a. If the CP ratio is $20 \%$, an increase in the amount of McK increases the spreading diameters of the mortars. In the case of using $20 \% \mathrm{CP}$, the use of $\mathrm{McK}$, which has a smaller average grain size than the limestone aggregate does, increases in the spreading diameter were observed. The reason for this is that the $\mathrm{McK}$ aggregate has more spherical structures than the limestone aggregate does. In addition, the hydrophobic property of the McK aggregate also contributes positively to this situation. In the case of using $25 \% \mathrm{McK}$ aggregate, a rise in $\mathrm{CP}$ ratio increases the spreading diameters. An increase in the workability because of an increase in the CP ratio that has a lower Blaine value than the BFS is an expected outcome. The use $\mathrm{CP}$ and $\mathrm{McK}$ at low ratios decrease the spreading diameters of the mortars.

The effect of the SS-W/B effect on the spreading properties of the mortars is given in Figure $3 \mathrm{~b}$. As seen in the $\mathrm{W} / \mathrm{B}$ ratios, the spreading diameters increase with an increase in the SS ratio. The reason for the increase of the spreading diameters along with the increase of the $\mathrm{SS}$ ratio is that SS has more water content than SH does. Also, SH's greater tendency to crystallise reduces the flow diameters. Furthermore, the change in the $\mathrm{W} / \mathrm{B}$ ratio does not affect the workability as much as the change in the $\mathrm{SS}$ rate.

The effects of the CP and W/B ratios on the spreading diameter are given in Figure $3 \mathrm{c}$. The change in the $\mathrm{CP}$ ratio is more effective than that of the $\mathrm{W} / \mathrm{B}$ ratio. The lower $\mathrm{CP}$ ratio at the different $\mathrm{W} / \mathrm{B}$ ratios is more positive in terms of the spreading diameter. Since the $\mathrm{CP}$ is hollower than the $\mathrm{BFS}$, the water absorption rate increases and, consequently, the spreading diameters decrease. Particularly, $50 \%$ usage of CP has greatly reduced the workability of the mortars. The flow diameters of the mixtures that contain $20 \% \mathrm{CP}$ and has a W/B ratio of 0.42 were measured as about $300 \mathrm{~mm}$. 


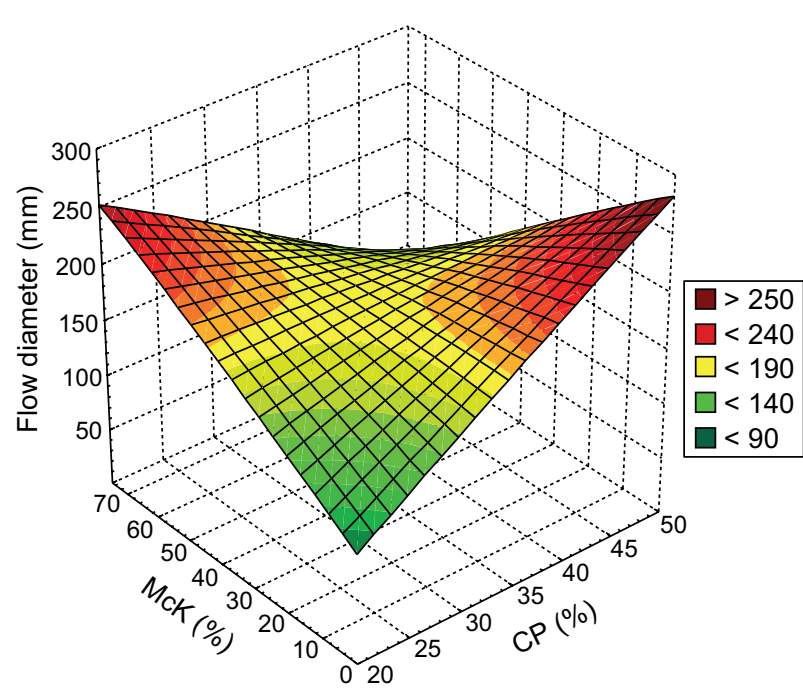

a) $\mathrm{CP}-\mathrm{McK}$ relationship

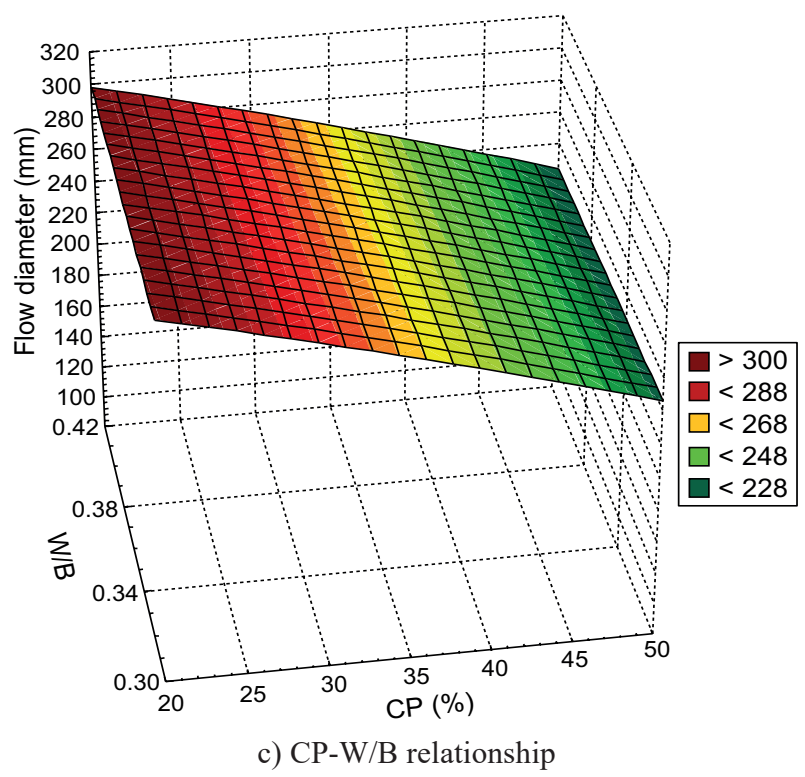

Figure 3. Parameters effective on the spreading diameter.

The effects of SS and McK on the workability are given in Figure $3 \mathrm{~d}$. The spreading diameters show an increase at different $\mathrm{McK}$ ratios with a rise in the SS ratio. As a result of the increase in the McK ratio due to the change in the SS ratio, the spreading diameters increase. The SS structure having a greater amount of water has a positive effect on the McK aggregate that consists of spherical grains.

\section{Compressive strength}

The effect of the $\mathrm{CP}$ ratio on the compressive strength on the $3^{\text {rd }}, 7^{\text {th }}$, and $28^{\text {th }}$ days is given in Figure 4a. In terms of the 3-day compressive strengths, it exceeds the value of $25 \mathrm{MPa}$ when the $\mathrm{CP}$ ratio is $20 \%$ and $30 \%$. However, if the CP ratio is $40 \%$ and $50 \%$, the 3-day compressive strengths decrease by about $10 \%$. When $20 \%$

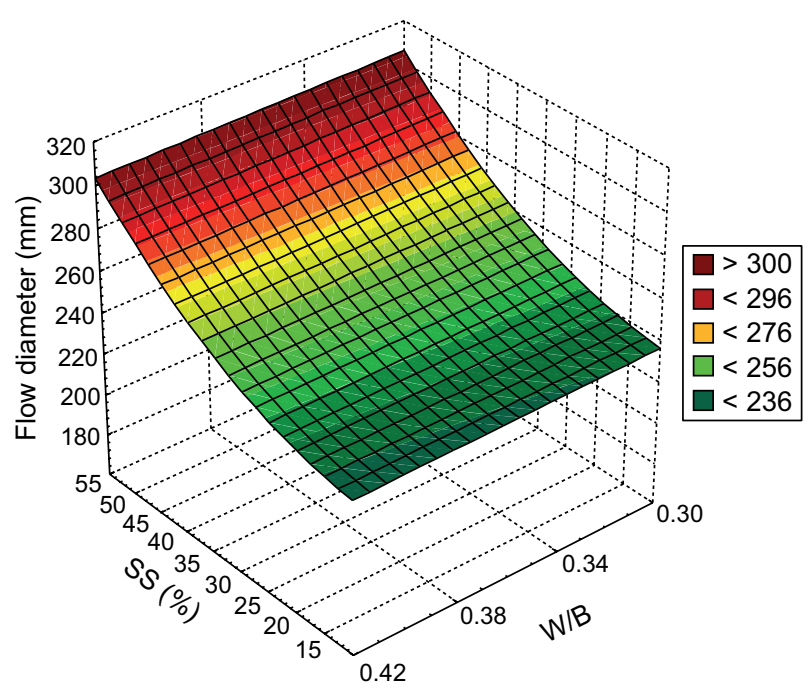

b) SS-W/B relationship

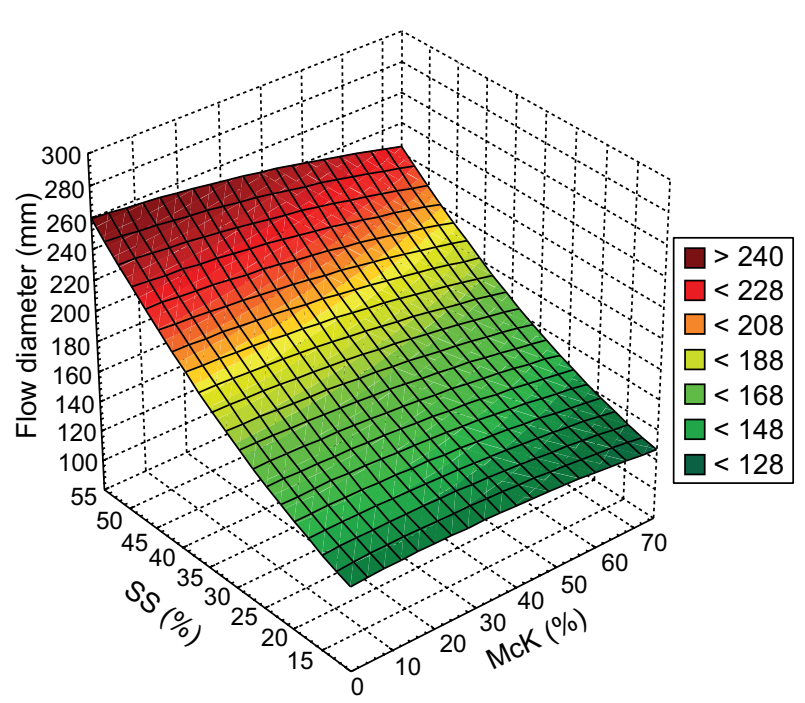

d) SS-McK relationship

$\mathrm{CP}$ is used, it is found that the speed of compressive strength recovery between the $3^{\text {rd }}$ and $7^{\text {th }}$ days is very low. The $50 \% \mathrm{CP}$ usage contributed significantly in compressive strength recovery on the $7^{\text {th }}$ day. In 7-day compressive strengths, the $30 \%$ and $40 \% \mathrm{CP}$ usage provided values below $30 \mathrm{MPa}$. On the other hand, when the 28-day compressive strengths are taken into consideration, over $40 \mathrm{MPa}$ strengths are obtained with $20 \%$ and $30 \%$ usage of the $\mathrm{CP}$. While $50 \% \mathrm{CP}$ usage had negative effects on the 3-day compressive strengths, it made it possible to obtain a strength of over $35 \mathrm{MPa}$ by contributing more on the $28^{\text {th }}$ day. The usage of the $\mathrm{CP}$ in ratios above 40 reduced the compressive strengths in all of the test days. As the usage ratio of the CP increases, which has a lower binding property in comparison with $\mathrm{BFS}$, the compressive strengths decrease. However, the pozzolanic property of the $\mathrm{CP}$ that has effect by the later 
ages ensures that the compressive strength is at least 30 MPa. $20 \%$ and $30 \%$ are more suitable as the optimal ratio for the $\mathrm{CP}$.

The effect of the McK ratio on the time-dependent compressive strength on the basis of days is given in Figure $4 \mathrm{~b}$. If the content of calcite is $0 \%$ and $25 \%$, the 3- and 7-day compressive strengths increase. High workability is obtained in some mixtures (particularly at a high $\mathrm{CP}$ ratio) when the calcite content is $0 \%$. This is thought to increase the compressive strength. Although using $50 \% \mathrm{McK}$ decreases the workability, it provides

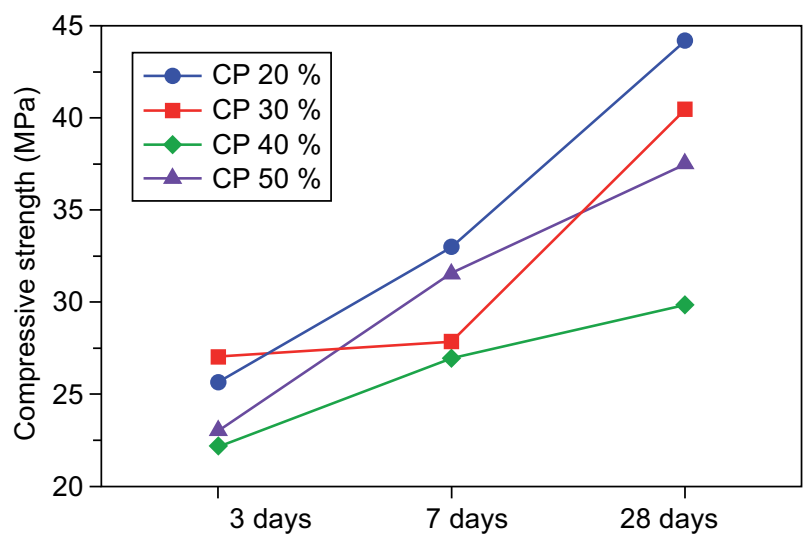

a) CP-strength relationship

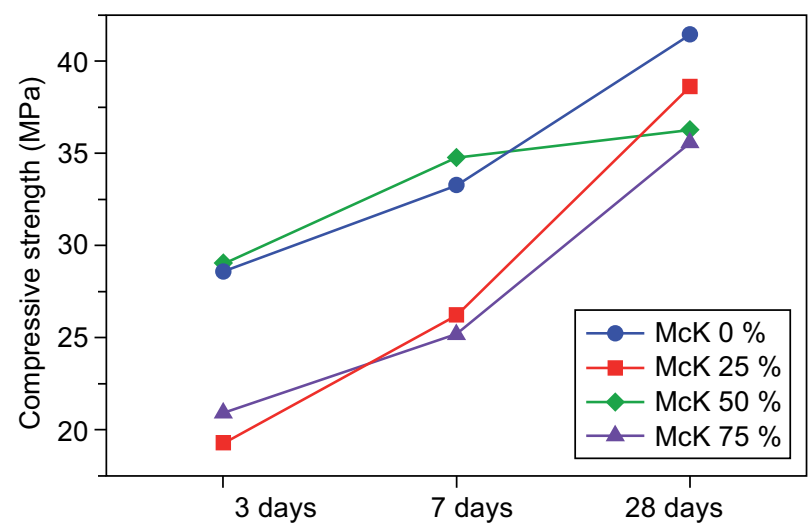

b) McK-strength relationship

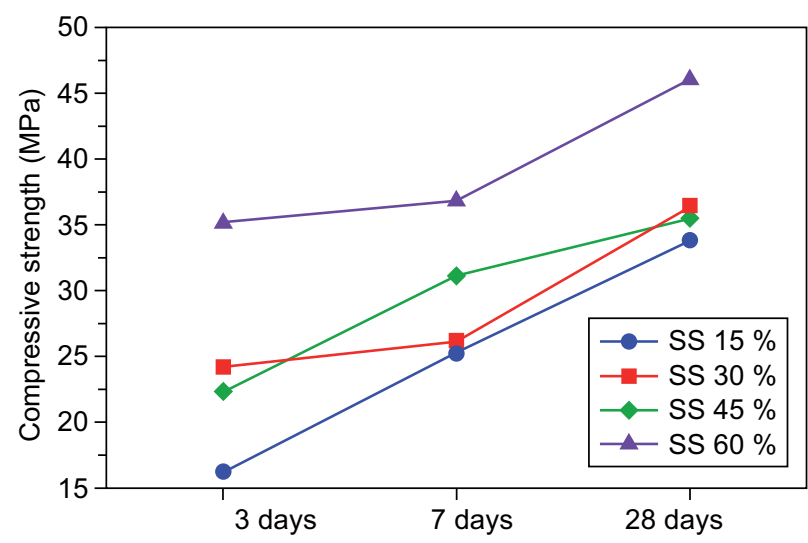

c) SS-strength relationship an increase in the compressive strength. This can be explained by the incorporation of smaller grains present in the McK to hydration. As a matter of fact, while $25 \%$ of McK usage increases the workability, the 3- and 7-day compressive strengths drop. It is thought that McK has a positive effect on early hydration with a nucleation effect up to $50 \%$ of the utilisation rate at the early ages. In terms of the 28-day compressive strengths, an increase in the McK ratio causes a drop in the compressive strengths. The McK ratio of $0 \%$ ensures that the 28day compressive strength is about $40 \mathrm{MPa}$. In the cases where the micronized aggregate was used, a stickiness problem occurred in the mixtures and some problems were encountered in the mould placement stage. This problem is parallel to the increase in the $\mathrm{McK}$ ratio. This problem caused a drop, particularly in the 28-day compressive strengths.

The effect of the SS ratio on the compressive strength is given in Figure 4c. Using $60 \% \mathrm{SS}$ increased the compressive strength on all the test days. The use of SS at $15 \%$ did not provide the desired results in the compressive strengths. However, even in the case of $15 \%$ SS usage, $30 \mathrm{MPa}$ was exceeded on the $28^{\text {th }}$ day. The compressive strengths showed increases with an increase in the SS. The low SS ratio reduces the reaction rate of the compounds solved by $\mathrm{SH}$.

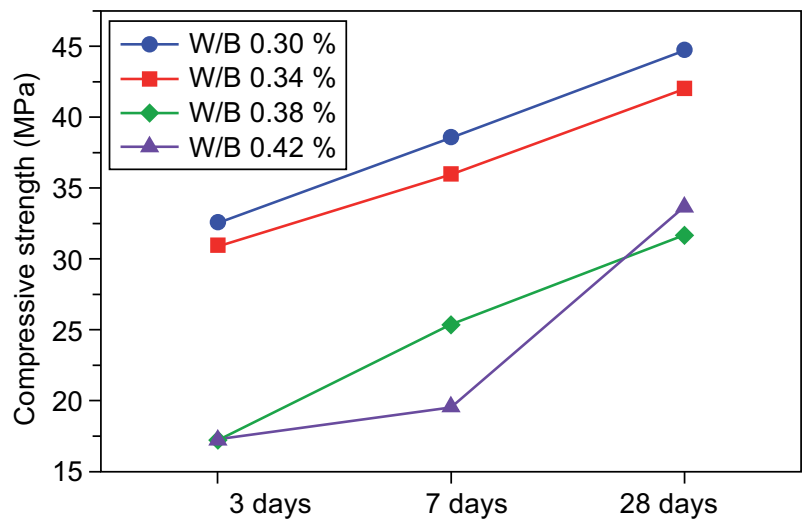

d) W/B-strength relationship

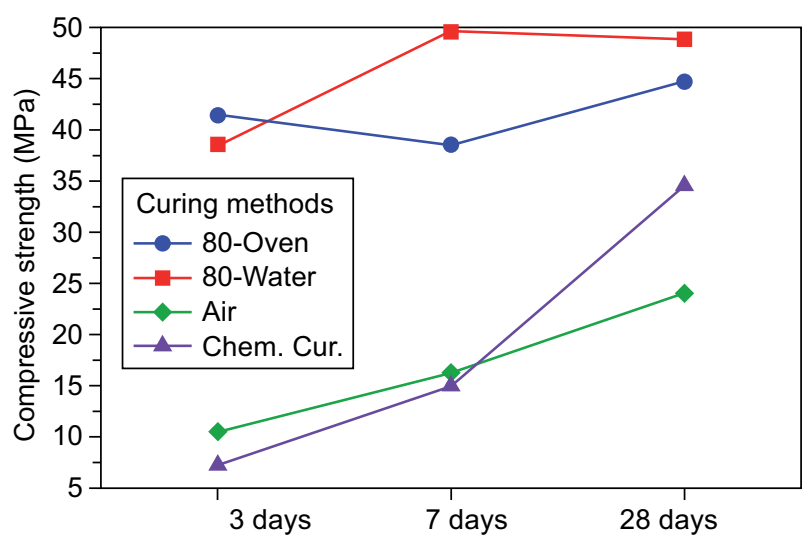

e) W/B-strength relationship

Figure 4. Effect of the Taguchi factors on the compressive strength. 
The effect of the W/B ratio on the time-dependent compressive strength is given in Figure 4d. As seen in Figure $4 d$, the compressive strengths show an increase with a decrease in the $\mathrm{W} / \mathrm{B}$ ratio. Only on the $28^{\text {th }}$ day, the compressive strengths of the mixtures with a $\mathrm{W} / \mathrm{B}$ ratio of 0.42 were higher than those with 0.38 . The difference in strengths between these mixtures is about $8 \%$. The reason for this difference is due to the lower workability of mixtures having a $\mathrm{W} / \mathrm{B}$ ratio of 0.38 . The $\mathrm{W} / \mathrm{B}$ ratio of 0.30 makes the 28-day compressive strength about $45 \mathrm{MPa}$.

The effect of the curing methods on the compressive strength is given in Figure 4e. It has been observed that thermal curing applied at $80^{\circ} \mathrm{C}$ is more positive. In terms of the 3-day compressive strengths, no significant differences have been observed between the oven and water cures applied at $80^{\circ} \mathrm{C}$. However, at the end of this period, the water cure applied at $80^{\circ} \mathrm{C}$ was found to be more effective. This situation is an indication that the presence of moisture in the curing of the AAMs contributes to an improvement of the compressive strength. Air curing and chemical cure methods showed similar strength properties until the $7^{\text {th }}$ day. It has been observed that the mortars subjected to a chemical curing method gained more compressive strength from the $7^{\text {th }}$ day onward and reached about $35 \mathrm{MPa}$ on the $28^{\text {th }}$ day. The hydration reaction slowed as a result of continuous water evaporation in the mortars, which were kept in the air. However, the chemical curing material delayed the evaporation of water in the mortar and enabled the mortars to gain more compressive strength. Mortar mixtures having a value of about $25 \mathrm{MPa}$ were obtained with air curing only.

\section{Optimisation}

Some durability experiments have been conducted by selecting 3 of the mortars produced according to the Taguchi L16 matrix. Optimisation was carried out based on the compressive strength and the workability tests. The $\mathrm{C}$ and $\mathrm{S}$ mixtures were selected based on their compressive strengths and the $\mathrm{W}$ mixture was selected based on its workability property. The $\mathrm{C}$ mixture was optimised for high compressive strength and the S mixture was optimised for a low compressive strength. In the $\mathrm{W}$ mixture, the mixing ratios to a high workability property were determined. The curing method has no effect on the workability in the $\mathrm{W}$ mixture. Therefore, to increase the compressive strength of the $\mathrm{W}$ mixture and to make it different than the $\mathrm{C}$ mixture, an oven cure was applied at $80^{\circ} \mathrm{C}$. The mixing ratios of the $\mathrm{C}, \mathrm{S}$, and $\mathrm{W}$ mortars are given in Table 4.

\section{Compressive strengths of optimum mortars}

The time-dependent compressive strengths of the mortars produced after the Taguchi optimisation are given in Figure 5. The compressive strength of about $85 \mathrm{MPa}$ has been obtained on the $28^{\text {th }}$ day in mortar C produced for the maximum compressive strength. In terms of early-age strength, a compressive strength of $70 \mathrm{MPa}$ was reached on the $3^{\text {rd }}$ day in mortar C. Eighty percent of the 28-day compressive strength in mortar C was obtained in 3 days. The time-dependent change in the compressive strength of mortar $\mathrm{C}$ showed a linear increase up to 28 days. In mortar $\mathrm{W}$, produced for workability, the application of an oven cure at $80^{\circ} \mathrm{C}$ provided high strengths. However, $90 \%$ of the 28 -day compressive strength in mortar $\mathrm{W}$ was obtained after a 3-day cure. Additionally, no significant increase was observed in the compressive strength of mortar $\mathrm{W}$ in comparison with other mortars after 3 days. The reason for the growth of the compressive strength of mortar $\mathrm{W}$ remaining constant is the oven curing process. Due to the depletion of ambient humidity during the oven curing process, the hydration process comes to a halt. In addition, the fact that the $\mathrm{W} / \mathrm{B}$ ratio of mortar $\mathrm{W}$ is 0.42 resulted in a decrease in the compressive strength. Because of the air curing of mortar S at $20^{\circ} \mathrm{C}$ and $75 \%$ relative humidity, a property of strength that shows an increase over time was observed, but the lack of

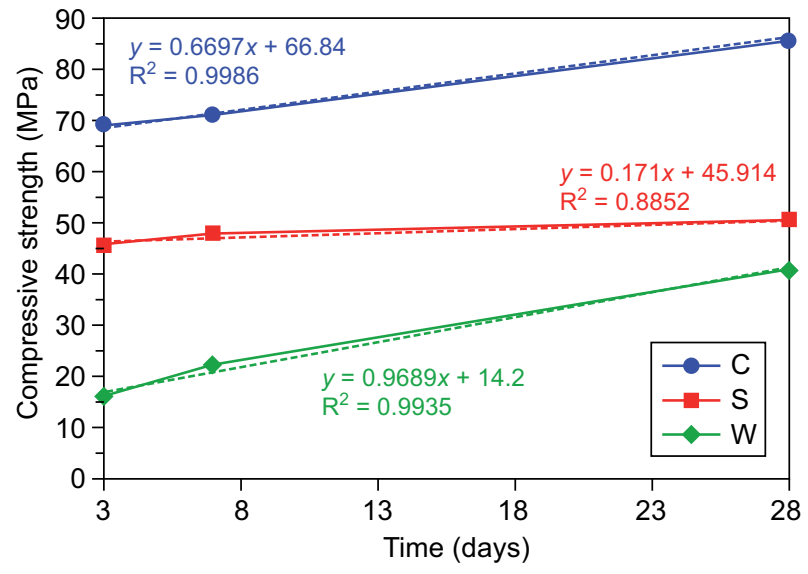

Figure 5. Compressive strengths of the optimum mortars.

Table 4. Mixing ratios as a result of the Taguchi optimisation.

\begin{tabular}{ccccccl}
\hline Mixture & CP $(\%)$ & McK $(\%)$ & SS $(\%)$ & W/B & Cure & Objective function \\
\hline $\mathrm{C}$ & 20 & 25 & 60 & 0.30 & $80^{\circ} \mathrm{C}$ (water) & Maximum compressive strength \\
$\mathrm{S}$ & 30 & 0 & 30 & 0.34 & Air & Minimum compressive strength \\
$\mathrm{W}$ & 40 & 50 & 45 & 0.42 & $80^{\circ} \mathrm{C}($ Oven $)$ & Maximum workability \\
\hline
\end{tabular}


thermal curing application particularly reduces the earlyage strengths. In mortar $\mathrm{S}$, a compressive strength of about $40 \mathrm{MPa}$ was obtained on the $28^{\text {th }}$ day. In the curing process for AAMs, the presence of moisture contributes toward the improvement of the strength. The increase in the $\mathrm{CP}$ ratio in the AAM production decreases the compressive strength, but this effect is reduced by the thermal curing processes.

\section{Sulfate resistance of} the optimum mortars

The sulfate resistance of the optimum mortars is given in Figure 6. The fact that mortar $\mathrm{C}$ is highest in terms of the compressive strength affects the sulfate resistance positively. Even though the 28-day compressive strength is high, the highest loss of strength took place in mortar C. After 180 days of the sodium sulfate effect, the compressive strength of about $60 \mathrm{MPa}$ was obtained and $32 \%$ loss of strength took place in the $\mathrm{C}$ series mortars, but after 60 days of the sodium sulfate effect, $17 \%$ loss of strength occurred. Keeping the mortars exposed to sodium sulfate effect increases the loss of strength over time.

The compressive strength of $\mathrm{S}$ is lower than that in the other mortar groups but it has more positive results in terms of the loss of strength. After 60 days of the sodium sulfate effect, there was a $5 \%$ loss of strength in the $\mathrm{S}$ mortar. After applying the sodium sulfate effect for 180 days, the loss of strength was $17 \%$. The loss of strength of the $\mathrm{S}$ series was less than that of $\mathrm{C}$ series in the sodium sulfate effect. This can be attributed to the increase in the $\mathrm{CP}$ ratio. As a result of a $30 \% \mathrm{CP}$ ratio, the $\mathrm{BFS}$ ratio decreases and consequently, the sulfate resistance increases relatively. The presence of $\mathrm{C}_{2} \mathrm{~S}$ in BFS causes the presence of $\mathrm{Ca}(\mathrm{OH})_{2}$ due to hydration, although in small amounts. That is why in terms of the sodium sulfate effect, the drop in the BFSA ratio decreases the loss of strength.

In the $\mathrm{W}$ mortar, just like in the $\mathrm{C}$ mortar, although high strengths were obtained after the curing process,

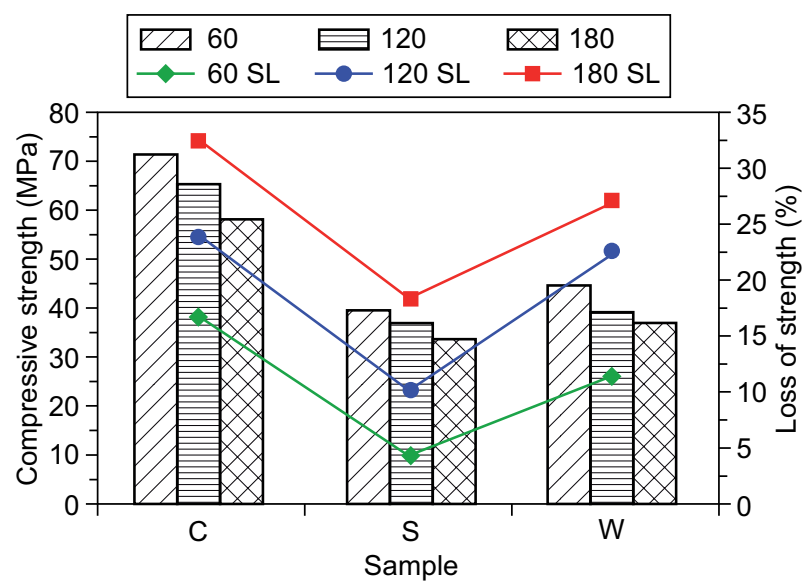

Figure 6. Sulfate resistance of the optimum mortars. high losses of strength occurred under the sodium sulfate effect. Especially, the sodium sulfate effect applied for 180 days caused a $28 \%$ loss of strength in the mortar structure. Although the $\mathrm{CP}$ ratio was $40 \%$, there was

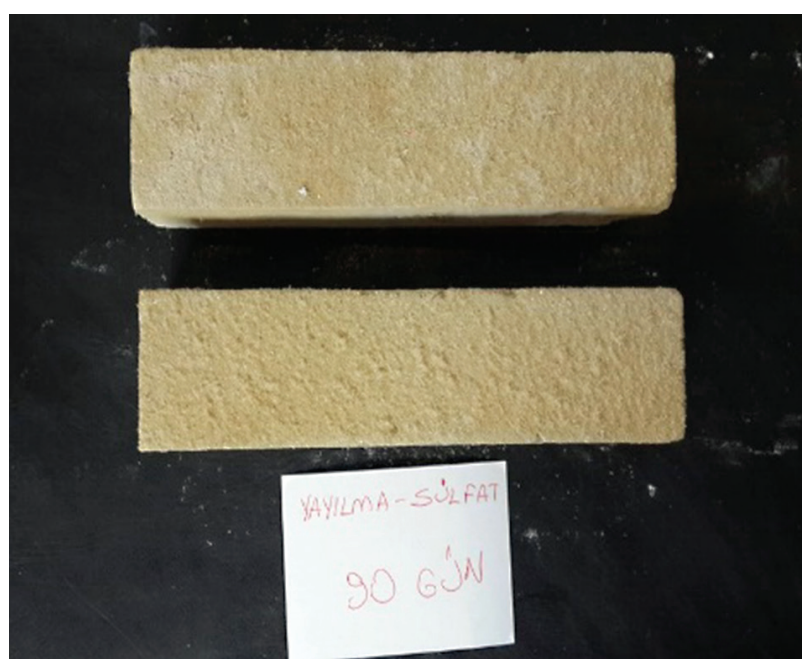

a)

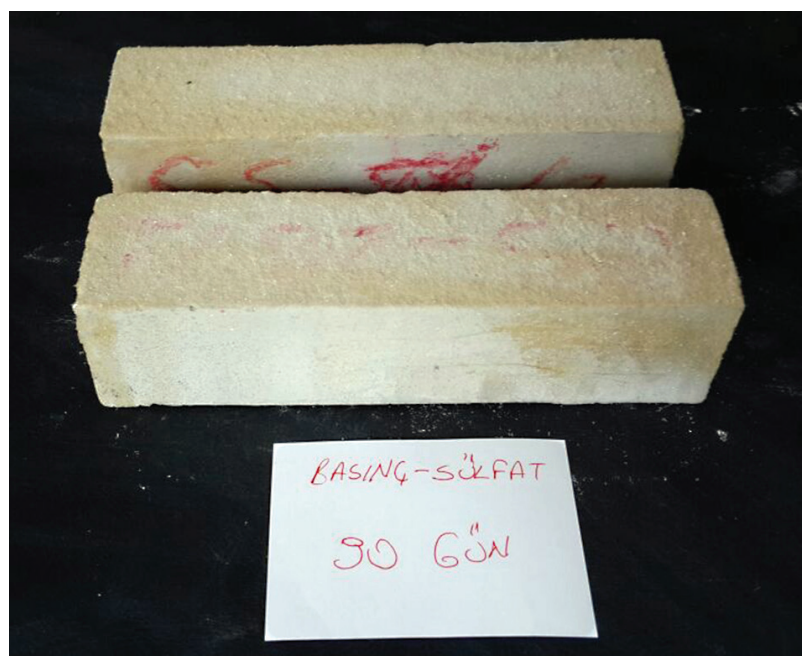

b)

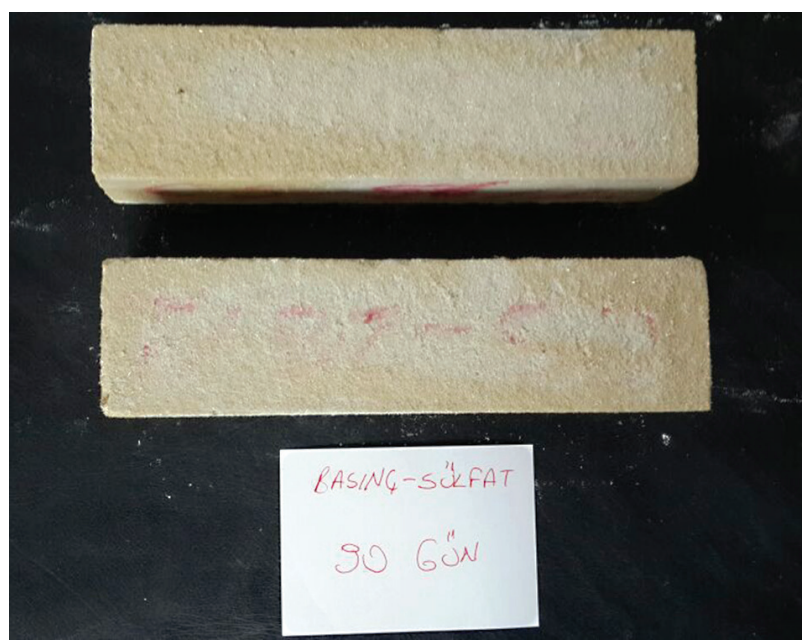

c)

Figure 7. The images of the AAMs in the $\mathrm{C}$ series after the sulfate effect (180 days). 
more strength loss than $\mathrm{S}$ series. The reason for the loss of strength in the $\mathrm{W}$ series can be explained with a high $\mathrm{W} / \mathrm{B}$ ratio $(0.42)$. The increase in $\mathrm{W} / \mathrm{B}$ ratio increased the permeability of the mortars and reduced the sulfate resistance. In terms of the sodium sulfate resistance, the use of CP with a low $\mathrm{W} / \mathrm{P}$ ratio and optimum ratios (30$40 \%$ ) provide more positive contributions.

As can be seen in Figure 7, no significant physical damage occurred to the structure of the mortars subjected to sodium sulfate for 180 days.

\section{Acid resistance of}

the optimum mortars

The behaviour of the optimum mortars against a sulfuric acid $\left(\mathrm{H}_{2} \mathrm{SO}_{4}\right)$ effect is given in Figure 8. It can be seen that the sulfate and acid resistance of the mortars showed similar properties.

As a result of exposing the $\mathrm{C}$ mortar to acid for 60 days, a $52 \%$ loss of strength occurred. It has been observed that the effect of sulfuric acid causes more loss of strength over time and that particularly, the 180-day acid effect led to about $72 \%$ strength loss in the mortars. The compressive strength of mortar $\mathrm{C}$ dropped below $25 \mathrm{MPa}$ as a result of the 180-day acid effect. Although the $\mathrm{W} / \mathrm{B}$ ratio is 0.30 and it has a high compressive strength, mortar $\mathrm{C}$ has lost its properties significantly under the acid effect. The reason for that, similar to the sulfate attack, is related to the high BSF content. The high content of $\mathrm{CaO}$ leads to the formation of $\mathrm{Ca}$-based compounds. But since these compounds dissolve more easily under an acid effect, the loss of strength was also high.

The use of $30 \% \mathrm{CP}$ in the $\mathrm{S}$ mortar contributed to the acid resistance. Although the compressive strength of the $\mathrm{S}$ mortar is low after the curing process, the loss of strength after the 180-day acid effect was about $48 \%$. As was the case under sulfate effect, the increase in the CP ratio contributed to the acid resistance.

Although $40 \% \mathrm{CP}$ was used in the $\mathrm{W}$ mortar, the fact that the $\mathrm{W} / \mathrm{B}$ ratio was 0.42 caused a loss of strength

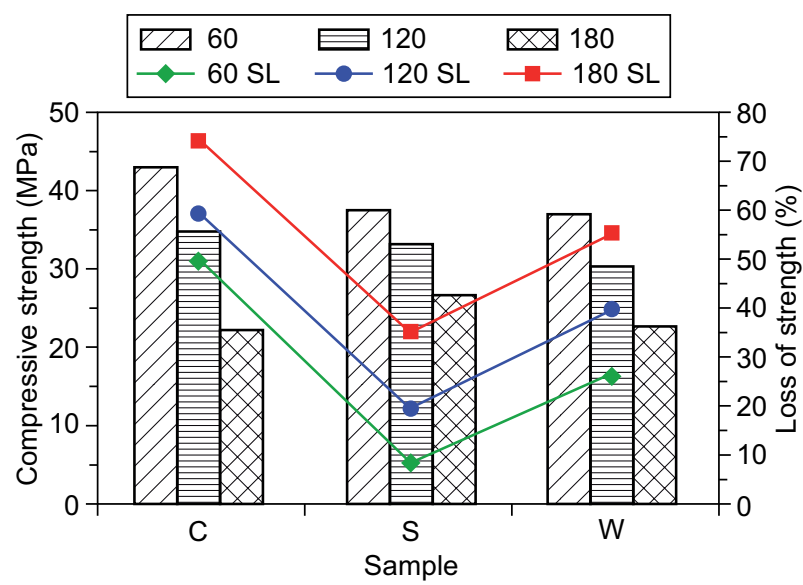

Figure 8. Acid resistance of the optimum mortars. against the acid effect. In mortar $\mathrm{W}$, the loss of strength was $22 \%$ after the 60-day acid effect and about $60 \%$ after the 180-day acid effect. The compressive strength of the W mortar dropped below $40 \mathrm{MPa}$ after the 180day acid effect.

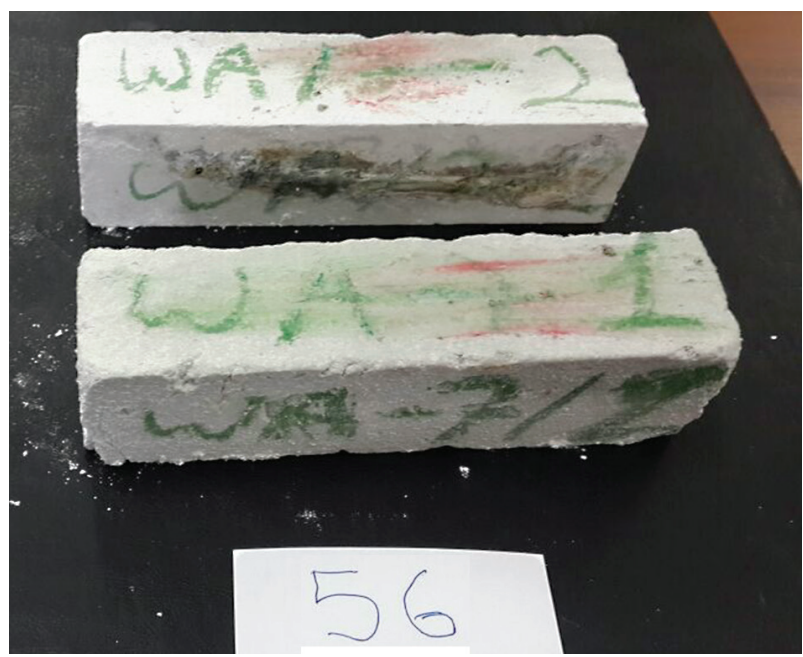

a)

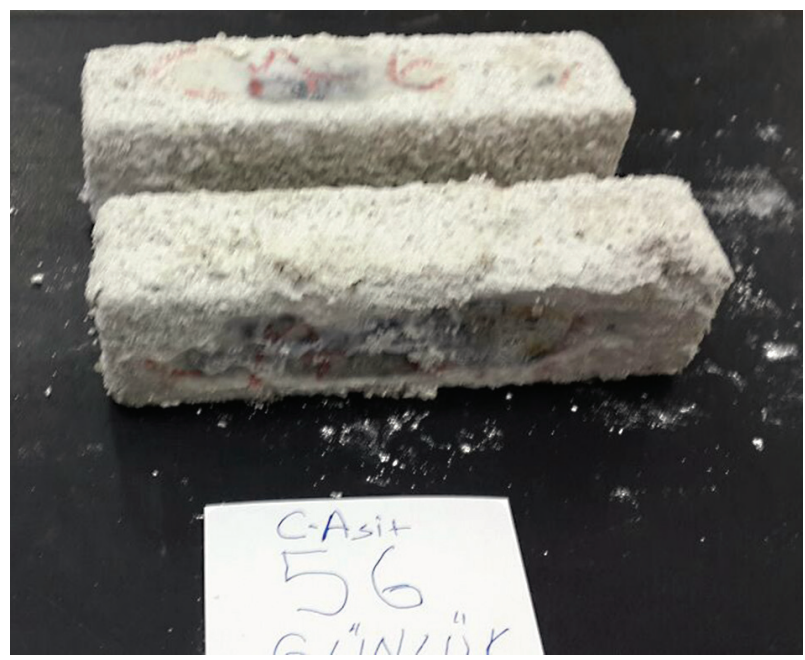

b)

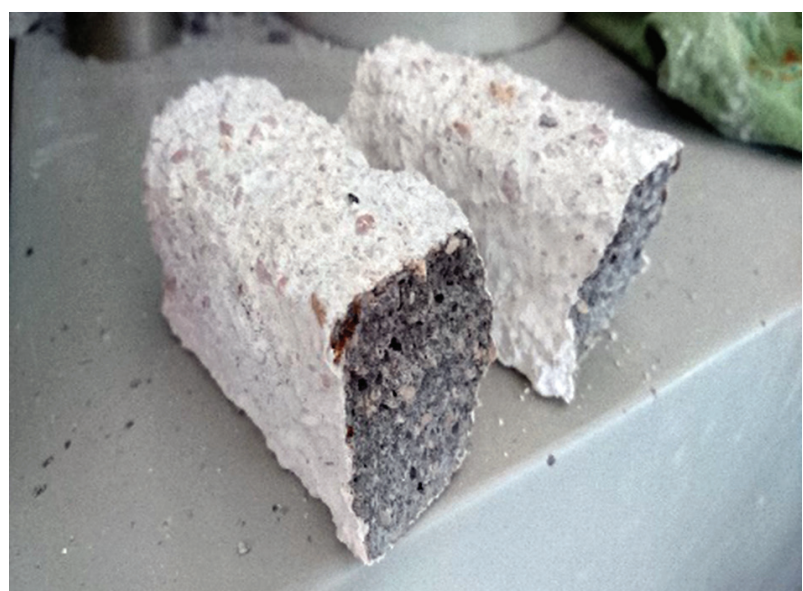

c)

Figure 9. Images of the AMMs of $\mathrm{W}$ and $\mathrm{C}$ after the acid effect (180 days). 
Although the $\mathrm{S}$ mortar has a $0.34 \mathrm{~W} / \mathrm{B}$ ratio and a low compressive strength based on the curing process, it sustained less loss of strength under the acid and sulfate effects. Among the reasons for the high loss of strength in the $\mathrm{C}$ and $\mathrm{W}$ mortars, it is thought that the use of McK is also an important factor. The use of $25 \% \mathrm{McK}$ and a high amount of BFS in the $\mathrm{C}$ mortar reduce the resistance against chemical effects. In the $\mathrm{W}$ mortar, the use of McK in a ratio of $50 \%$ increases the loss of strength in comparison with the S mortar, but the use of $40 \%$ $\mathrm{CP}$ prevented the further increase in the loss of strength. Therefore, the mineralogical structure of the aggregate filling material becomes important in the AAM designs made against chemical effects.

As shown in Figure 9, the C coded AMM has sustained more physical damage under the acid effect. But the W coded AMM containing $40 \% \mathrm{CP}$ sustained less physical damage.

\section{High temperature endurance of optimum mortars}

The behaviours of the optimum mortars against $300^{\circ} \mathrm{C}, 600^{\circ} \mathrm{C}$, and $900^{\circ} \mathrm{C}$ effects are given in Figure 10 . About $32 \%$ losses of strength and compressive strength of about $66 \mathrm{MPa}$ have been obtained in mortar $\mathrm{C}$ subjected to a high-temperature effect applied at $300^{\circ} \mathrm{C}$. A strength of $44 \%$ and compressive strength of below $30 \mathrm{MPa}$ were obtained at $600^{\circ} \mathrm{C}$. As expected, the highest loss of strength in the $\mathrm{C}$ mortar occurred at $900^{\circ} \mathrm{C}$. A high loss of strength with a value of $85 \%$ occurred at $900^{\circ} \mathrm{C}$. The low W/B ratio of the $\mathrm{C}$ mortar shows that its porosity is lower than those of other mortar groups. The smaller diameter of the cavity in mortars with low porosity causes greater damage under the high-temperature effect. The water, which is separated from the hydration products under the effect of high temperature, causes more damage by creating vapour pressure in the mortar structure.

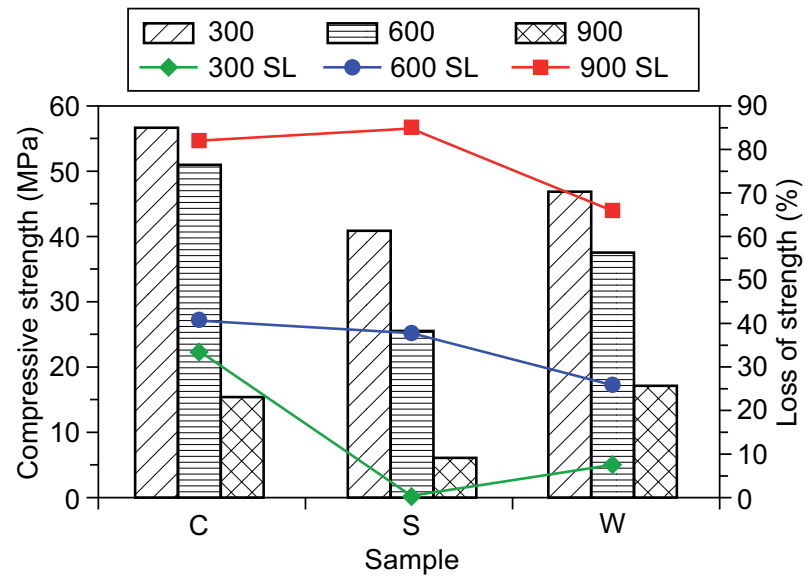

a) Compressive strengths
In the $\mathrm{S}$ mortar, no significant loss of strength occurred and a compressive strength of $\sim 42 \mathrm{MPa}$ was obtained at $300^{\circ} \mathrm{C}$. A $40 \%$ loss of strength occurred at $600^{\circ} \mathrm{C}$. At temperatures of $300^{\circ} \mathrm{C}$ and $600^{\circ} \mathrm{C}$, the loss of strength of the $\mathrm{S}$ mortar is less than that of the $\mathrm{C}$ mortar. This may be explained by the use of $30 \% \mathrm{CP}$ in the $\mathrm{S}$ mortar. If baked clay products are used in cement-based composites, they increase the resistance to the hightemperature effect. But at $900^{\circ} \mathrm{C}$, the loss of strength in the $\mathrm{S}$ mortar is greater than that of the $\mathrm{C}$ mortar. The lower 28-day compressive strength of the $\mathrm{S}$ mortar caused it to sustain more loss of strength at $900^{\circ} \mathrm{C}$.

Approximately a $5 \%$ loss of strength and a compressive strength of about $66 \mathrm{MPa}$ took place in the W mortar at $300^{\circ} \mathrm{C}$. In the $\mathrm{W}$ mortar at $600^{\circ} \mathrm{C}$ and $900^{\circ} \mathrm{C}$, less loss of strength occurred than that in the $\mathrm{C}$ and $\mathrm{S}$ mortars. The reason for less loss of strength is linked to the use of $40 \% \mathrm{CP}$ in the $\mathrm{W}$ mortar. Furthermore, use of $50 \% \mathrm{McK}$ in the $\mathrm{W}$ mortar also contributed to the high temperature endurance. The fact that the carbonate-based aggregates are more resistant to the high-temperature effects has reduced the loss of strength of the AAMs. The fact that McK aggregate has smaller grain size especially contributed more to this effect.

As shown in Figure 10b, in terms of the dynamic elasticity modulus, the high-temperature effect at $300^{\circ} \mathrm{C}$ has not caused significant variations. But the high-temperature effect applied to the mortars at 600 and $900^{\circ} \mathrm{C}$, has greatly reduced the dynamic elasticity modulus. Since the dynamic elasticity modulus is a parameter based on unit weight, the decrease in the dynamic elasticity modulus with an increase in the high temperature degree is an expected occurrence. Especially the decomposition of the carbonates at $900^{\circ} \mathrm{C}$ increases the weight loss. The high-temperature effect applied to the $\mathrm{S}$ mortar that has a lower 28-day compressive strength caused a further reduction of the dynamic elasticity modulus. The ineffective curing process has resulted in poor hydration product bonds and caused damage to the mortar under the high-temperature effects. The use of $40 \% \mathrm{CP}$ and the effect of $50 \% \mathrm{McK}$ in the $\mathrm{W}$ mortar led to lower loses in the dynamic elasticity modulus.

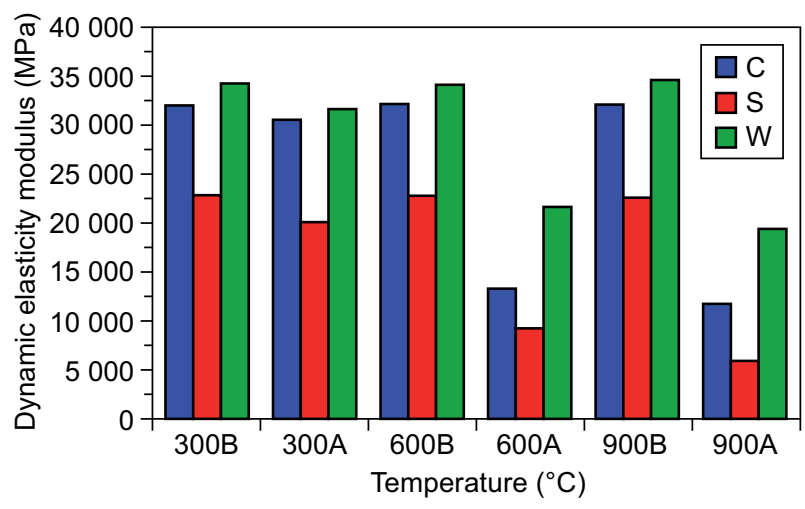

b) Dynamic elasticity modulus

Figure 10. Compressive strengths (a) and dynamic elasticity modulus (b) of the mortars under the high-temperature effect. 
MemişS., Kaplan G., Yaprak H., Yilmazoğlu M. U., Mütevvelli Özkan I. G.

Figure 11 shows the surface properties of the AAMs exposed to $900^{\circ} \mathrm{C}$. It has been observed that more physical cracks occurred in the $\mathrm{C}$ and $\mathrm{W}$ coded AAMs. Although the W coded AAM sustained less loss of strength, there are significant cracks on the surface.

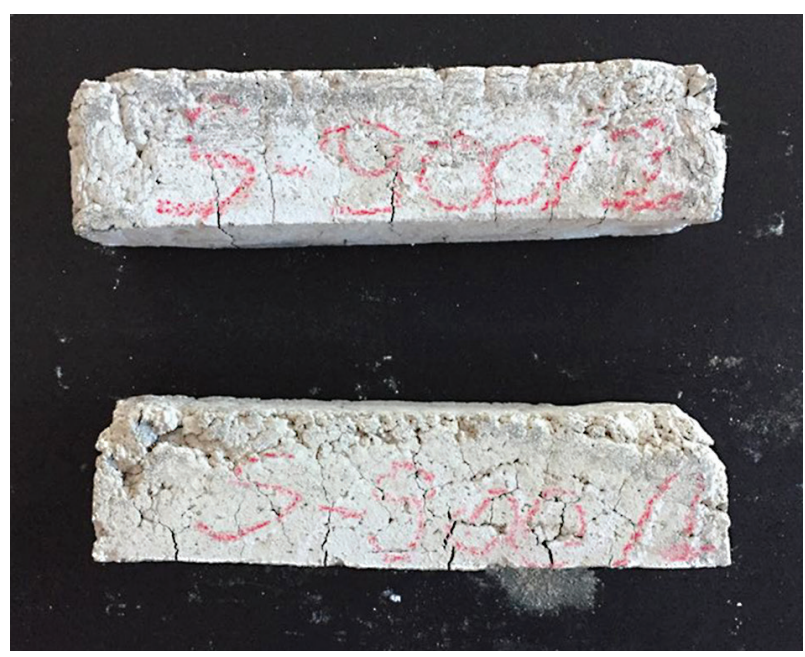

a)

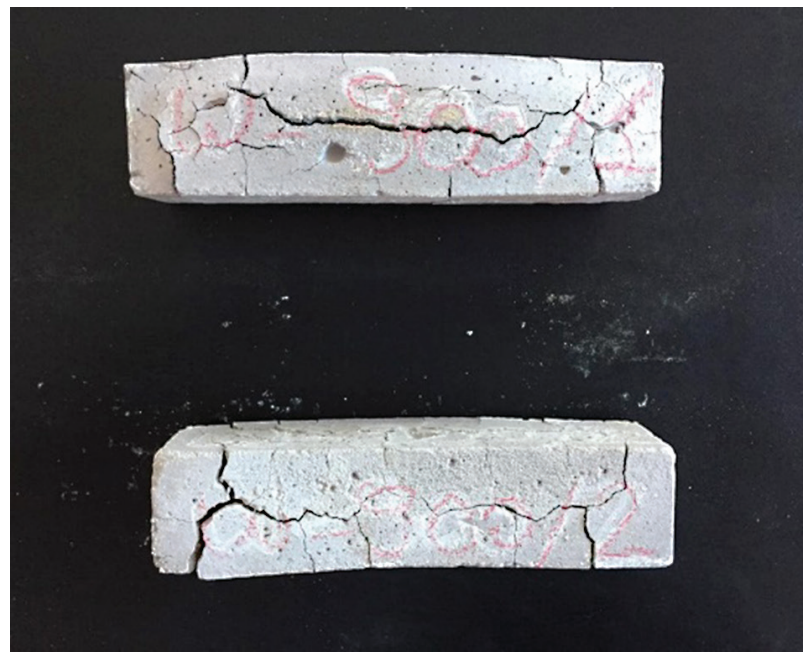

b)

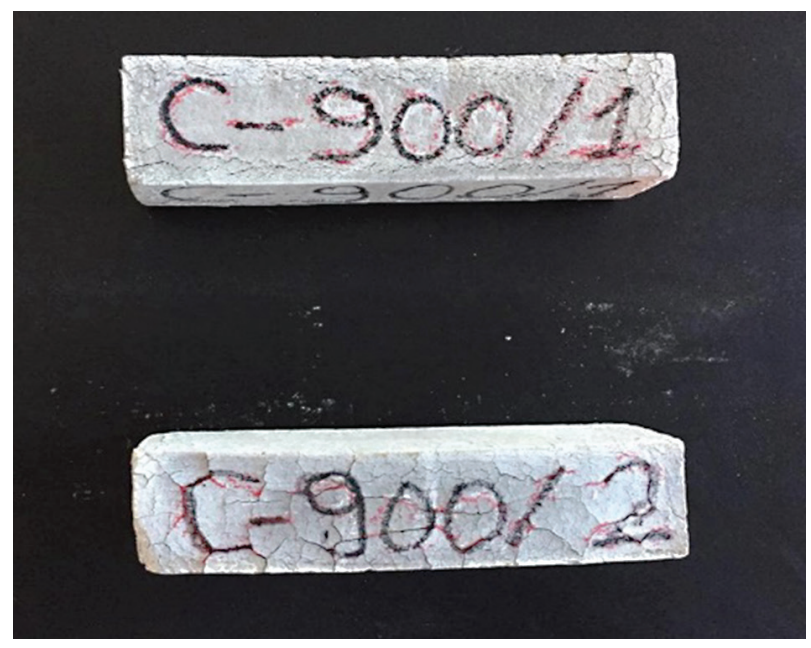

c)

Figure 11. Images of mortars exposed to a $900^{\circ} \mathrm{C}$ temperature.
The low loss of strength indicates that the web of cracks remains on the surface and does not reach very deep.

\section{Freezing-Thawing resistance of optimum mortars}

The compressive strengths and loss of strengths of the mortars resulting from 50,100, and 200 cycles of freezing-thawing are given in Figure 12. The compressive strengths decrease with an increase in the number of freezing-thawing cycles applied to the mortars. When 50 and 100 cycles were applied to the $\mathrm{C}$ mortar, a loss of strength of $46 \%$ and $52 \%$ occurred, respectively. After 100 cycles, the compressive strength of the $\mathrm{C}$ mortar dropped below $50 \mathrm{MPa}$. Although the loss of strength was at about $75 \%$ at 200 cycles, it caused a compressive strength of about $23 \mathrm{MPa}$.

Similar results were obtained against the freezingthawing resistance in mortar $\mathrm{W}$ also. About a $50 \%$ loss of strength occurred in the mortar structure between 50 and 100 cycles. The greatest loss of strength in the $\mathrm{W}$ mortar was at 200 cycles and a $75 \%$ loss of strength was observed. The $\mathrm{C}$ and $\mathrm{W}$ mortars showed similar properties in terms of the compressive strength values.

In the $\mathrm{S}$ mortar, relatively more loss of strength occurred in comparison to the $\mathrm{C}$ and $\mathrm{W}$ mortars. Using $\mathrm{McK}$ in the $\mathrm{S}$ mortar increased the permeability of the mortars and caused the loss of strength ratio to increase. Additionally, the fact that the S mortar had a lower compressive strength than that of the other mortar groups before the freezing-thawing procedure reduces the resistance against the freeze effect. The filling material used in the aggregate becomes important for the permeability. When the $\mathrm{W}$ and $\mathrm{C}$ mortars are compared, the $0.42 \mathrm{~W} / \mathrm{B}$ ratio of the $\mathrm{W}$ mortar was a factor in reducing the freezing-thawing resistance.

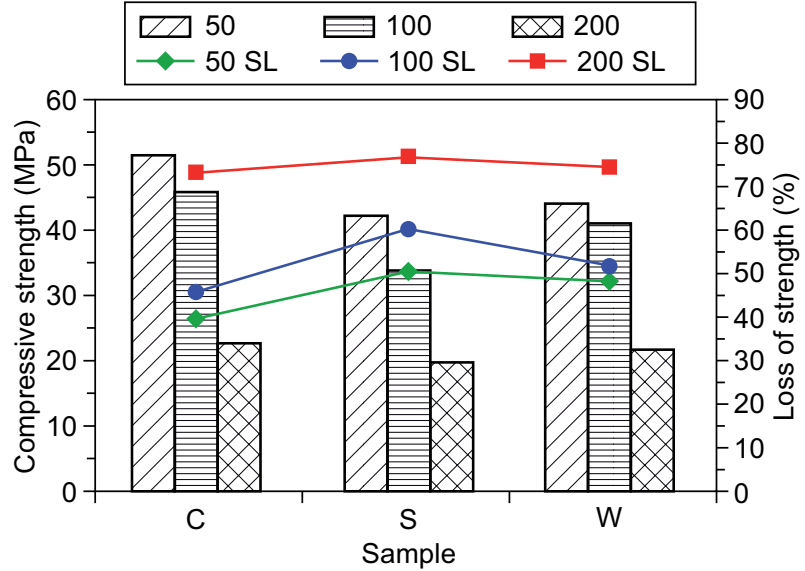

Figure 12. Freezing-Thawing resistance of the optimum mortars. 


\section{CONCLUSIONS}

The use of McK with a spherical structure, which works as a substitute for a calcareous aggregate, contributes to a workability up to $25 \%$. But since its average grain size is smaller than that of the calcareous aggregate, the workability was reduced significantly at $50 \%$ and $75 \%$ ratios. While the use of $30 \% \mathrm{CP}$ decreased the workability, using $40 \%$ and $50 \% \mathrm{CP}$ raised the workability. The fact that the substitution material of the $\mathrm{CP}$ has a lower Blaine value than that of BFS contributes to this situation. An increase in the SS and W/B ratios increases the workability. Due to the higher water content of the SS than the SH, the workability increased. Since $16 \mathrm{M} \mathrm{SH}$ was prepared, it increased the amount of the solid content and decreased the workability.

As is the case with conventional concrete, the compressive strengths usually decrease with an increase in the $\mathrm{W} / \mathrm{B}$ ratio. As a result of an increase in the $\mathrm{CP}$ ratio, the 7-day and 28-day compressive strengths decrease. The fact that the hydraulic properties of the $\mathrm{CP}$ are less than those of BFS negatively affects the compressive strengths. Using $40 \% \mathrm{CP}$, which has a low Blaine value and hydraulic properties, increased the workability, and it caused the compressive strength to decrease. This situation caused an inverse proportion to occur between the workability and the compressive strength. Using $50 \%$ $\mathrm{McK}$ increased the3-day compressive strengths; whereas, for the 28-day compressive strengths, an increase in the $\mathrm{McK}$ ratio reduces the compressive strengths. In terms of the curing methods, while the hot water curing applied at $80^{\circ} \mathrm{C}$ increased the compressive strengths, the 28 -day compressive strengths of the mortars that were left outdoors decreased. Furthermore, as was the case in the chemical curing, the presence of moisture played an important role in terms of the compressive strengths of the AAMs. An increase in the SS ratio usually increases the compressive strengths. Particularly, the fact that the SS ratio is $60 \%$ ensured the compressive strengths to be $45 \mathrm{MPa}$ and above. The $60 \% \mathrm{SS}$ makes a positive contribution to the geopolymerisation process. As is the case in conventional concrete, an increase in the W/B ratio reduces the compressive strengths.

In the case of chemical attacks, such as sodium sulfate and sulfuric acid, more loss in strength occurred depending on the high BFS content. The fact that BFS has a high $\mathrm{CaO}$ content and the presence of $\mathrm{C}_{2} \mathrm{~S}$ causes the formation of Ca-based compounds. However, since these compounds are solved easily as a result of the chemical attacks, more losses in the strength occurred.

Using a carbonate-based filling material instead of aggregates increases the high-temperature endurance. In addition, using baked clay products such as $\mathrm{CP}$ instead of BFS reduces the damage sustained due to high-temperature effect. As a result of using $40 \% \mathrm{CP}$ and $50 \%$ $\mathrm{McK}$, there have been fewer losses in the dynamic elasticity modulus.
Since the filling material used as the aggregate substitution affects the cavity structure, it has been determined as a factor that decreases permeability. The present compressive strengths of the mortars and the W/B ratio have great importance in terms of the freezing-thawing resistance.

In the AAM production, it is possible to produce AAMs that have a compressive strength of $50 \mathrm{MPa}$ using $40 \% \mathrm{CP}$ and $50 \% \mathrm{McK}$. Furthermore, the usability of ceramic waste in the AAM production becomes possible, and the ceramic waste contributed more toward the hightemperature endurance in the AAMs.

\section{Acknowledgment}

This study was supported by the Research Projects Unit (BAP) of Kastamonu University as a research project numbered KÜBAP-05 / 2015.9.

\section{REFERENCES}

1. Pacheco-Torgal F., Castro-Gomes J., Jalali S. (2008): Alkaliactivated binders: A review. Part 1. Historical background, terminology, reaction mechanisms and hydration products. Construction and Building Materials, 22(7), 1305-1314. doi: 10.1016/j.conbuildmat.2007.10.015

2. Hossain M. M., Karim M. R., Hossain M. K., Islam M. N., Zain M. F. M. (2015): Durability of mortar and concrete containing alkali-activated binder with pozzolans: A review. Construction and Building Materials, 93, 95-109. doi: 10.1016/j.conbuildmat.2015.05.094

3. Mehta P. K. (1977): Properties of blended cements made from rice husk ash. In Journal Proceedings, 74( 9), 440-442.

4. Islam A., Alengaram U. J., Jumaat M. Z., Bashar I. I., Kabir S. A. (2015): Engineering properties and carbon footprint of ground granulated blast-furnace slag-palm oil fuel ashbased structural geopolymer concrete. Construction and Building Materials, 101, 503-521. doi: 10.1016/jconbuildmat. 2015.10.026

5. Ranjbar N., Mehrali M., Alengaram U. J., Metselaar H. S. C., Jumaat M. Z. (2014): Compressive strength and microstructural analysis of fly ash/palm oil fuel ash based geopolymer mortar under elevated temperatures. Construction and building materials, 65, 114-121. doi: 10.1016/j. conbuildmat.2014.04.064

6. Kabir S. M., Alengaram U. J., Jumaat M. Z., Sharmin A., Islam A. (2015): Influence of molarity and chemical composition on the development of compressive strength in POFA based geopolymer mortar. Advances in Materials Science and Engineering, 2015, 1-15. doi: 10.1155/2015/ 647071

7. Albitar M., Ali M. M., Visintin P., Drechsler M. (2015): Effect of granulated lead smelter slag on strength of fly ash-based geopolymer concrete. Construction and Building Materials, 83, 128-135. doi: 10.1016/j.conbuildmat.2015. 03.009

8. Albitar M., Visintin P., Ali M. M., Drechsler M. (2015): Assessing behaviour of fresh and hardened geopolymer concrete mixed with class-F fly ash. KSCE Journal of Civil 
Engineering, 19(5), 1445-1455. doi: 10.1007/s12205-0141254-z

9. Albitar M., Ali M. M., Visintin P., Drechsler M. (2017): Durability evaluation of geopolymer and conventional concretes. Construction and Building Materials, 136, 374-385. doi: 10.1016/j.conbuildmat.2017.01.056

10. Bakharev T. (2005): Durability of geopolymer materials in sodium and magnesium sulfate solutions. Cement and Concrete Research, 35(6), 1233-1246. doi: 10.1016/j.cemconres.2004.09.002

11. Bakharev T. (2005): Resistance of geopolymer materials to acid attack. Cement and Concrete Research, 35(4), 658-670. doi: 10.1016/j.cemconres.2004.06.005

12. Albitar M., Visintin P., Ali M. M., Lavigne O., Gamboa E. (2016): Bond slip models for uncorroded and corroded steel reinforcement in class-F fly ash geopolymer concrete. Journal of Materials in Civil Engineering, 29(1), 04016186. doi: 10.1061/(ASCE)MT.1943-5533.0001713

13 Bilek V., Hurta J., Done P., Zidek L. (2016): Development of alkali-activated concrete for structures - Mechanical properties and durability. Perspectives in Science, 7, 190-194. doi: 10.1016/j.pisc.2015.11.031

14. Provis J. L. (2017). Alkali-activated materials. Cement and Concrete Research, article in press. doi: 10.1016/j.cemconres.2017.02.009

15. Bilek V. (2011). Slag alkaline concrete with mineral admixture," in: $13^{\text {th }}$ International Congress on the Chemistry of Cement., pp. 1-7.

16. Mithun B. M., Narasimhan M. C. (2016): Performance of alkali activated slag concrete mixes incorporating copper slag as fine aggregate. Journal of Cleaner Production, 112 , 837-844. doi: 10.1016/j.jclepro.2015.06.026

17. Adam A. A. (2009). Strength and Durability Properties of Alkali Activated Slag and Fly Ash-Based Geopolymer Concrete. Thesis, RMIT University

18. Shi C. (2003): Corrosion resistance of alkali-activated slag cement. Advances in Cement Research, 15(2), 77-81. doi: 10.1680/adcr.2003.15.2.77

19. Fernández-Jiménez A., García-Lodeiro I., Palomo A. (2007): Durability of alkali-activated fly ash cementitious materials. Journal of Materials Science, 42(9), 3055-3065. doi: 10.1007/s10853-006-0584-8

20. Bondar, D., Lynsdale C. J., Milestone N. B., Hassani N. (2012): Oxygen and chloride permeability of alkaliactivated natural pozzolan concrete. ACI Materials Journal, 109(1), 53-61.
21. Roy D. M., Jiang W., Silsbee M. R. (2000): Chloride diffusion in ordinary, blended, and alkali-activated cement pastes and its relation to other properties. Cement and Concrete Research, 30(12), 1879-1884. doi: 10.1016/S00088846(00)00406-3

22. Zhu H., Zhang Z., Zhu Y., Tian L. (2014): Durability of alkali-activated fly ash concrete: chloride penetration in pastes and mortars. Construction and Building Materials, 65, 51-59. doi: 10.1016/j.conbuildmat.2014.04.110

23. Ismail I., Bernal S. A., Provis J. L., San Nicolas R., Brice D. G., Kilcullen A. R., Hamdam S., van Deventer J. S. (2013): Influence of fly ash on the water and chloride permeability of alkali-activated slag mortars and concretes. Construction and Building Materials, 48, 1187-1201. doi: 10.1016/j.conbuildmat.2013.07.106

24. Bakharev T., Sanjayan J. G., Cheng Y. B. (2002): Sulfate attack on alkali-activated slag concrete. Cement and Concrete Research, 32(2), 211-216. doi: 10.1016/S0008-8846 (01)00659-7

25. Pan Z., Li D., Yu J., Yang N. (2003): Properties and microstructure of the hardened alkali-activated red mudslag cementitious material. Cement and Concrete Research, 33(9), 1437-1441. doi: 10.1016/S0008-8846(03)00093-0

26. Ismail I., Bernal S. A., Provis J. L., Hamdan S., van Deventer J. S. (2013): Microstructural changes in alkali activated fly ash/slag geopolymers with sulfate exposure. Materials and Structures, 46(3), 361-373. doi: 10.1617/ s11527-012-9906-2

27. Yusuf M. O. (2015): Performance of slag blended alkaline activated palm oil fuel ash mortar in sulfate environments. Construction and Building Materials, 98, 417-424. doi: 10.1016/j.conbuildmat.2015.07.012

28. Lloyd R. R., Provis J. L., van Deventer J. S. (2012): Acid resistance of inorganic polymer binders. 1. Corrosion rate. Materials and Structures, 45(1-2), 1-14. doi: 10.1617/ s11527-011-9744-7

29. Bernal S. A., Rodríguez E. D., Mejía de Gutiérrez R., Provis, J. L. (2012): Performance of alkali-activated slag mortars exposed to acids. Journal of Sustainable CementBased Materials, 1(3), 138-151.

30. Qian J., Shi C., Wang Z. (2001): Activation of blended cements containing fly ash. Cement and Concrete Research, 31(8), 1121-1127. doi: 10.1016/S0008-8846(01)00526-9

31. Zhang J., Shi C., Zhang Z., Ou Z. (2017): Durability of alkaliactivated materials in aggressive environments: A review on recent studies. Construction and Building Materials, 152, 598-613. doi: 10.1016/j.conbuildmat.2017.07.027 